\title{
Innovative Model of SME Development
}

\author{
Uliana Berezhnytska \\ Applied Economy Department \\ Ivano-Frankivsk National Technical \\ University of Oil and Gas \\ Ivano-Frankivsk, Ukraine \\ bi_if@ukr.net
}

\begin{abstract}
Report provides an insight into the characteristics and advantages of small and medium entrepreneurship (SME) as an innovative and progressive sector of development of social oriented market economy. The article analyzes the SME activity in Ukraine and reveals the position of our country compared to other EU countries (Poland for instance) in terms of level of SME development and business conditions for it. The results of the article represented in the innovative model of SME development, which includes the special characteristics of SMEs and factors of influence on it as well as the performance positive effect of SMEs functioning (namely economic and social impacts). The paper suggests recommendations of taking into account the innovative model and distinctive features of SMEs in order to intensify the SME development, firstly in Ukraine.
\end{abstract}

Keywords-small and medium-sized enterprises (SMEs), distinctive features, SME development, innovative model

\section{INTRODUCTION}

Among former socialist countries, Ukraine remains a state with multifaceted problem of market economy forming. The socialization of market mechanism of a country should considered primarily as well as using innovative institutions of development.

The most important, progressive and fully innovative institute for development of market economy is the small and medium entrepreneurship (SME), which is often referred to as a separate "small" sector of national economy. Although the necessity of SME development does not need to substantiated, but the question why this needed not raised in today's society in practical and scientific fields.

The investigation of specific distinctive features of small and medium-sized enterprises (SMEs) and designing them in an integrated model of SME development will allow the identifying ways of innovative development of market economy, in our country particularly.

This sector contributes to the socialization of economy and has significant innovative potential since it contains, for the most part, a great intellectual component. At the same time, globalization and excessive liberalization implies the emergence and the presence of a number of challenges, especially for such institute as SME. That enhances the relevance of this study.

Many scientists have investigated the problems of SME development. Fundamental works in that context are the papers of S. Dryha [1] and I. Mantsurov [2], which focused on the forming an institutional environment for SME development, the need for special state policy for this sector of economy, the evaluation of effectiveness of SMEs activity for national economy [3]. Z. Varnaliy [4] and T. Vasyltsiv [5] have also an important experience in development of institutions for SMEs, but paid more attention to the economic security of entrepreneurship and effective relations between the state and small businesses [6].

The fundamental works of A. Butenko [7], V. Heiets, S. Sobol [8], L. Ligonenko, K. Liapina, D. Liapin and others cannot overlooked. Speaking about restrictive factors for SMEs development and the role of SME in competitiveness of national economy, we must also emphasize such scientist as P. Kolisnichenko [9]. However, without diminishing the role of researches of mentioned above scholars, it is necessary to focus more on distinctive features of SME as unique innovative institute of development.

SME development is one of the main drivers of economic growth and, consequently, contributes to improving the population's quality of life. In particular, SMEs create new jobs, increase tax revenues, foster innovative development of regions and country as a whole.

Therefore, the purpose of this study is to determine the specific distinctive features of SMEs in innovative model of SME development. Quantitative and qualitative indicators of SMEs functioning in Ukraine also analyzed in order to gain the better understanding of the needs and concerns of SME as a separate institute of development. Thus, a comprehensive approach to building an innovative model of SME development will help us to identify the ways and directions of intensifying the policy of SME support and, accordingly, further economic and social effect from SME activeness in future.

\section{DEFINITION AND ANALYSIS OF SME}

The definition of an SME is important firstly for access to finance and support programs targeted specifically at these enterprises. The definition of SME in Ukraine is set out in Article 55 of the Commercial Code of Ukraine [10] and is mostly identical to that what EU Commission defines [11].

The dynamics of SME development indicators in Ukraine analyzed since 2013.

In particular, the number of SMEs was growing to 2015. In 2016 , this indicator decreased by $5.5 \%$ compared to 2015 , and in 2017 - by $3.2 \%$ (Figure 1).

In 2017, there were 425 SMEs per 10 thousand people in Ukraine (Figure 2). Over the last three years, this indicator has tended to decline, mainly due to the discontinuation of activity by individual entrepreneurs because of unstable political and economic conditions. 


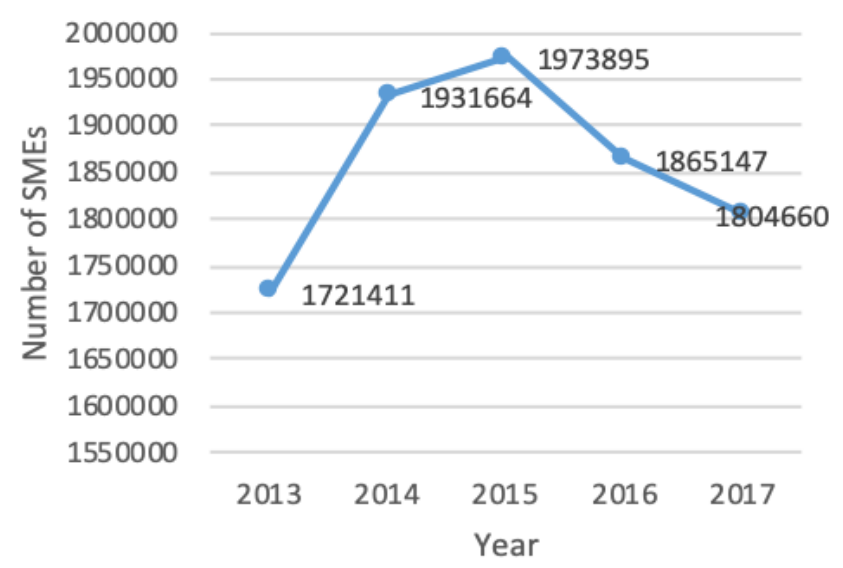

Fig. 1. Number of SMEs in Ukraine during 2013-2017 [12]

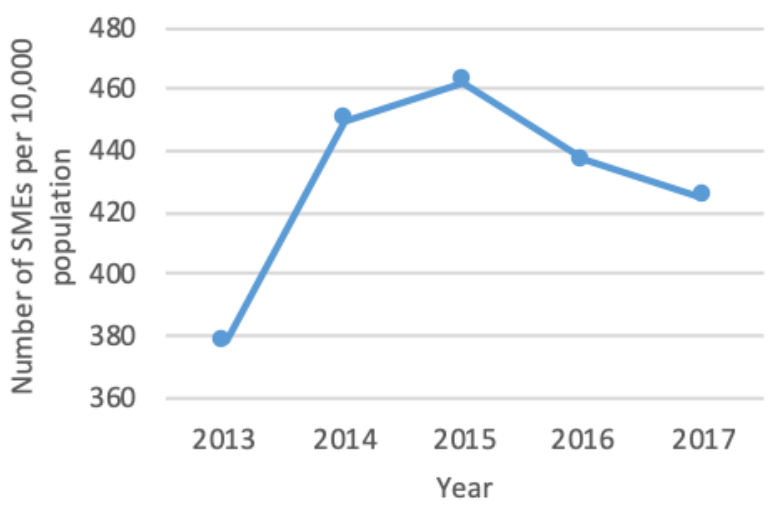

Fig. 2. Number of SMEs in Ukraine per 10,000 people in 2013-2017 [12]

Volume of sales tends to increase (Figure 3). In 2014, it increased by $3.8 \%$ compared to the previous year, in 2015 by $28.9 \%$, in 2016 - by $23.7 \%$, and in 2017 - by $24.2 \%$. However, one of the main reasons for that was the high rate of inflation, but not "natural" causes of increasing.

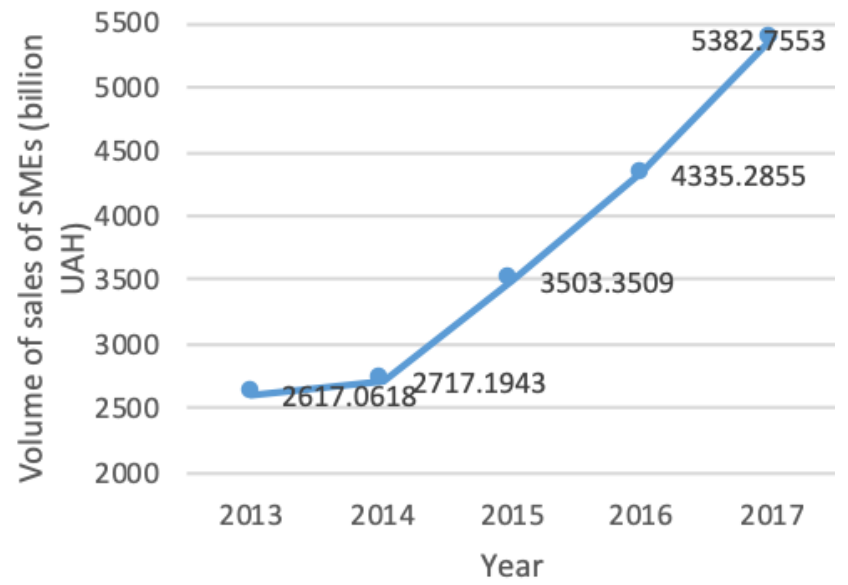

Fig. 3. Volume of sales of SMEs during 2013-2017 [12]

The structure of SMEs by type of economic activity in 2018 presented in Figure 4.

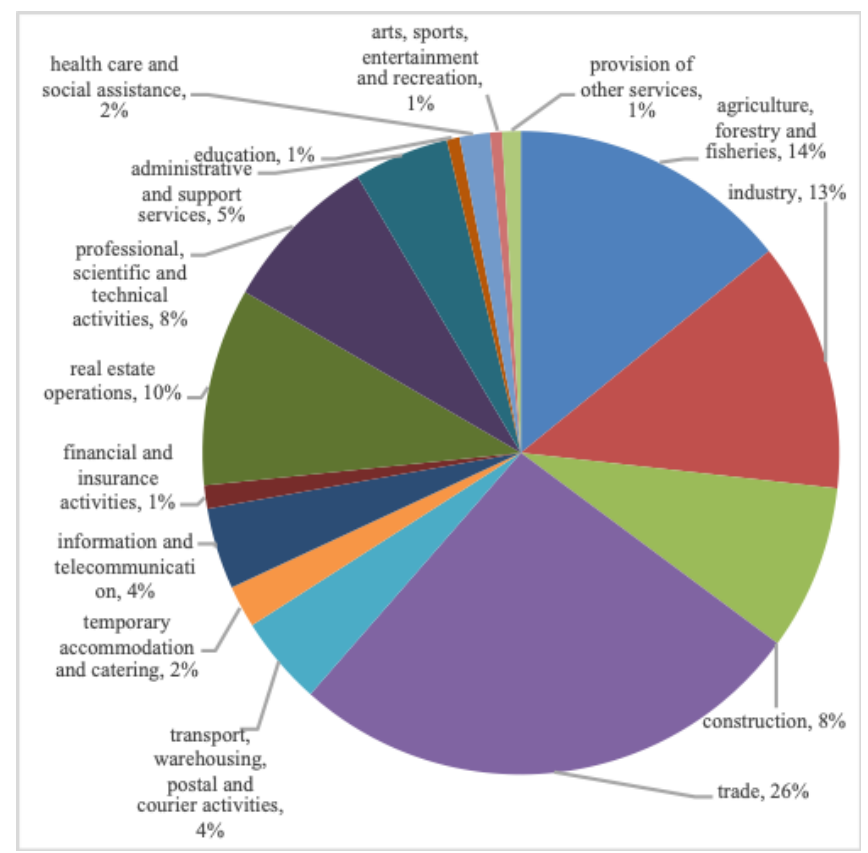

Fig. 4. Structure of SMEs by type of economic activity in Ukraine in $2018, \%$ [12]

For compering, in terms of SME structure in Poland, service companies predominate $(51.7 \%)$, followed by trade (24.9\%), building (13.1\%) and industry (10.3\%) [13].

In the same time, the largest number of SMEs in Ukraine are involved in trade $(26.4 \%)$, followed by agriculture, forestry and fisheries (14.2\%), industry (12.6\%) and real estate operations $(9.9 \%)$.

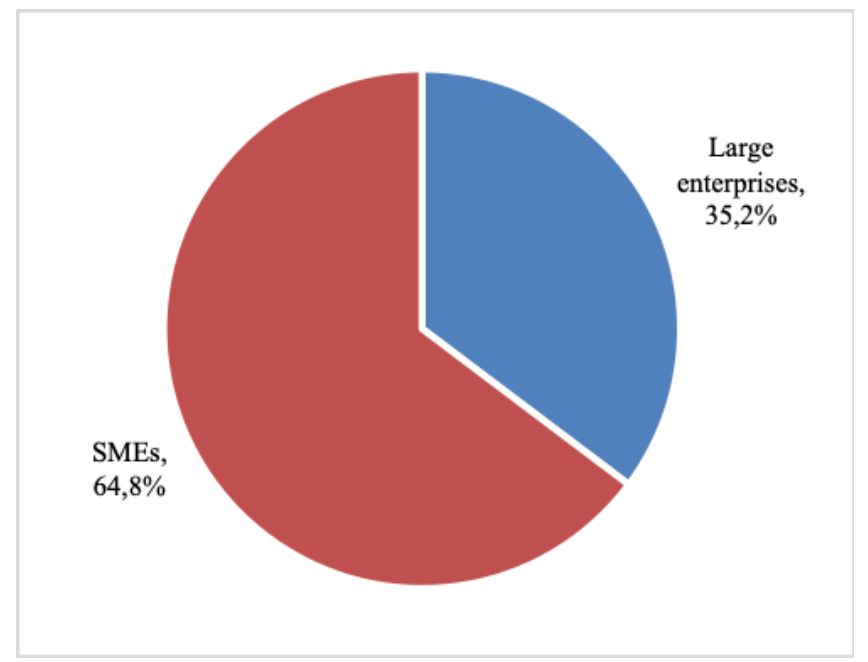

Fig. 5. Share of products sold by SMEs and large enterprises in Ukraine in 2017 [12]

In Poland, SME makes up more than $99.8 \%$ of the total number of enterprises and only $0.2 \%$ is large enterprises [13]. The share of SME sector in Germany is $99.51 \%$ in total quantity of businesses [14]. SME in Ukraine counts $99.98 \%$ of total quantity of enterprises [14].

It should also note that $75-81 \%$ of all workers in Poland employed in SME during the last 5 years [13]. This fact indicates the real importance of SMEs in creation of new jobs and solution of other social problems. 


\section{MODELING OF SME DEVELOPMENT}

In order to fully characterize this innovative institute of market economy the model of SME development should be considered. This model presented in Figure 6.

Numerous scientists [15] - [17] who have researched the features SMEs and SME development have similar approaches to determining the factors of influence on this sector of economy.

In this model of SME development, the emphasis placed on specific distinctive features and the importance of SMEs for economy and society. Below is a detailed analysis of the distinctive features of SMEs, which we can present after looking at the practical functioning of SMEs in Ukraine and Poland as a close to us EU country.

\section{A. Innovativeness and development potential}

They should quickly challenge inefficient elements and introduce innovations in order not to be swallowed by their strong competitors. Innovativeness is fully applied in small and medium-sized business, as SMEs are forced to conquer the market at the expense of innovative ideas.

At the same time, as SMEs are often knowledge-based, they are a catalyst for the innovative development and the knowledge economy as a whole.

\section{B. Mobility and flexibility}

Due to their size, SMEs do not have a significant economic effect on scale, but their advantage is territorial mobility, which allows choosing the optimum region of activity and target segment. SMEs can also change their form and type of activity faster. Therefore, we can confirm that SMEs are characterized by absolute mobility. They can faster adapt their products to the changes of the market requirements as they are not producing large quantities of goods and services.

\section{Fast decision making}

The organizational structure is often simple because owners mostly make decisions themselves. The absence of dependence on third parties is a positive feature. The advantage is the absence of duplication of management functions and the inability to create any misunderstandings about this.

\section{Revenue generation}

SMEs generate a significant portion of income, which contributes to the economic security of the region and the state as a whole. Of course, the primary purpose of setting up and running an entrepreneurial business is to generate income. It should also be noted that this advantage of SMEs forms a strong middle class society.

\section{E. Employment}

SMEs envisage self-employment for the entrepreneurial population, as well as the creation of numerous new jobs. Thus, the development of SMEs solves the painful social problem - unemployment.

\section{F. Risk-taking}

The activities of SMEs carried out at their own risk. However, in this case, commercial risk can interpreted in a special way, because the risk is mainly due to their own savings, and the flexibility and frequent diversification of business creates new and new types of risks. It should be noted that the topic of SME risk is interesting for further research.

\section{G. Finansial independence (mostly self-finansing)}

SMEs are, for the most part, financially independent as they use mostly their own funds. Banks and other financial institutions are reluctant to work with newcomers, so access to finance is very limited. SMEs can rely on government and grant funds.

\section{H. Initiative}

SMEs activity is autonomous and proactive. The ability to produce a new product and take the initiative and responsibility for your own future is a specific feature of an entrepreneur who started a small or medium-sized business; because not everyone is capable of such an initiative (such entrepreneurs can be called leaders in life). Of course, it is much easier and more peaceful to earn a wage as an employee than at every step to take the risk, take the initiative and generate something new.

\section{Fostering the competitive economy}

They are preventing monopoly of big enterprises. SMEs produce a competitive environment and saturate the market with the necessary goods. Both the economic and social impact of SME development ensured by the simultaneous development of competition and free market.

\section{J. Key role in forming the middle class society}

SMEs play a key role in shaping the middle class, which is the basis of civil society. SMEs are usually a progressive force that remains economically, politically and socially active.

A good example in this context is the revolution of dignity in Ukraine, where small entrepreneurs and representatives of middle-sized enterprises played an important role in supporting and financing it.

\section{K. Focus on quality and personalization}

They are not oriented on mass production. Therefore, SMEs can respond to the demand for personalized products. This is a logical explanation for "conquering your consumer" solely by meeting his individual needs.

\section{Social responsibility and formation of civil society}

SMEs are socially active, taking part in solving a number of social problems. "Social" entrepreneurs and intellectual businesses, where often the main purpose of the activity is not to make a profit, but to achieve another, social goal are also worth mentioning. Important is self-realization, constant self-development and self-improvement of such entrepreneurs, which also enhances their social activity. Initiative people who take responsibility for themselves rarely remain out of touch with the needs of society.

\section{Local focus and prevalence}

The sectors of economy that are in demand at the local level (with competitive advantages in the region) are developing first and foremost. At the same time, SMEs are developing and able to expand their scope of activity. 


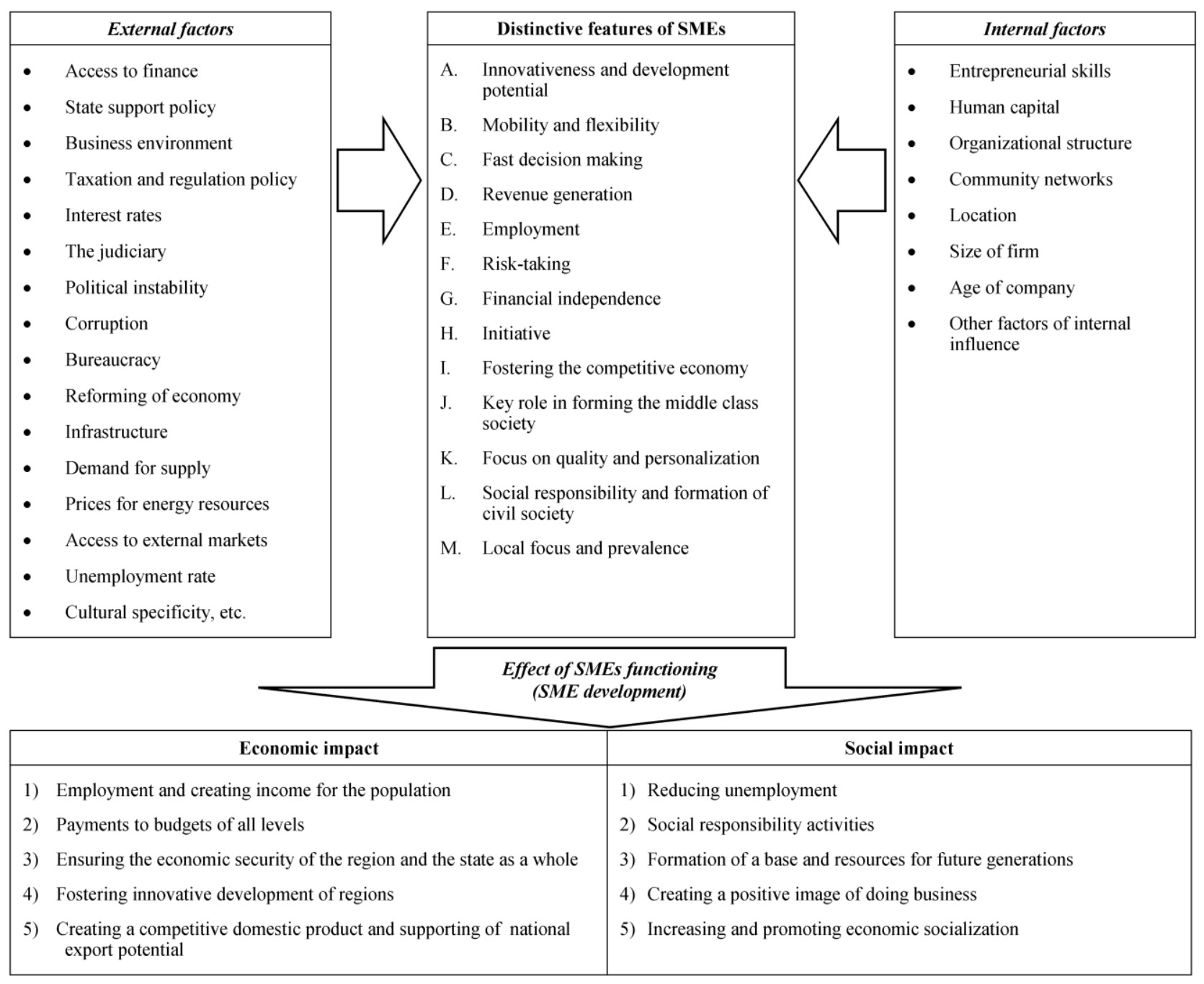

Fig. 6. Innovative model of SME development

The factors of external and internal environment of SMEs, designed in the model above, characterize the specific situations in particular areas. For instance, a high level of such an external factor as "corruption" will have a strong negative impact for SME development, and a low one of it on the contrary. Therefore, named external and internal factors in the innovative model of SME development, we wanted to fix the separate spheres, to show where they are appearing, without focusing on directions of their actions. Moreover, a number of researches of SME factors on different levels (national, local, etc.), mostly that inhibit entrepreneurial activity, are the quite numerous and such studies are investigated sufficiently ([9] as an example).

The innovative model of SME development also outlines the main aspects of the economic and social impact of SMEs on economy and society as a whole, which ensured precisely by the functioning and development of SMEs.

\section{CONClusions}

1) SME is an institute for development of innovative market economy that additionally provides solutions to a number of social problems. In particular, SMEs play an essential role in filling the budgets of all levels, reducing unemployment through self-employment and job creation, generates incomes for population that improves the total life quality.

This sector of economy has the significant innovativeness and intellectual potential. As a large amount of small and medium-sized businesses are engaged in innovation and intellectual activity, they are actively participating in innovative events, introducing new forms of businesses and new technologies. In such foresee, it is extremely important of creating and supporting a various forms of organization an innovation activity of SMEs that involving to this process educational, scientific institutions, state and big business.

2) The separate proper policy of SME support much needed, as SMEs are quite vulnerable and sensitive to any changes, especially to the influence of external environment. However, due to the considerable potential for development, SME are able to provide positive economic and social impact (effect) primarily at the local level, as well as the state's.

3) A clear understanding of specific features of this "small" sector of economy gives an opportunity to identify the SMEs needs and priority areas of SME support policy and, as a consequence, to ensure the innovative development and growth of the national economy. 
Thus, the designed SME development innovative model makes possible to comprehensively and visually assess the aforementioned characteristics of SMEs, which should be taken into account in further SME supporting activity.

\section{REFERENCES}

[1] S. H. Dryha, Small Entrepreneurship of Ukraine: formation, management and support mechanisms. Kyiv, Ukraine: Lybid, 2009. [in Ukrainian].

[2] I. H. Mantsurov, Institutial Planning in the System of State Regulation of Economy. Kyiv, Ukraine: Research Economic Institute, 2011. [in Ukrainian]

[3] I. H. Mantsurov, S. S. Vaschaev, S. H. Dryha, O. A. Chupryna, A. V. Yatsenko, Development of Small Enterprises (statistic evaluation of the impact on economic growth and copetitiveness of the country). Kyiv, Ukraine: KNEU, 2009. [in Ukrainian].

[4] Z. S. Varnaliy, Small Business: the foundations of theory and practice. Kyiv, Ukraine: Knowledge, 2001. [in Ukrainian]

[5] T. H. Vasyltsiv, Economic Security of Ukrainian Entrepreneurship: Strategy and Mechanisms of Strengthening. Lviv, Ukraine: Aral, 2008. [in Ukrainian].

[6] Z. S. Varnaliy, S. H. Dryha, L. L. Tarangul, Microcrediting of Small Business. Kyiv, Ukraine: Irpin, 2008. [in Ukrainian].

[7] A. I. Butenko, The Potential of Small Business in the Paradigm of Sustainable Development. Kyiv, Ukraine: Interprint, 2012. [in Ukrainian].

[8] S. M. Sobol, "Evaluation of structural changes in the small business sector of Ukraine", 2018. [Online]. Available: http://ir.kneu.edu.ua/bitstream/handle/2010/24180/146149.pdf;jsessionid=CCD7F5007C33189EBC68AF012D1C39EA?seq uence $=1$. [in Ukrainian].

[9] P. T. Kolisnichenko, "Features, Trends and Alternative Ways to Improve the Effectiveness Of Small and Medium Enterprises in Ukraine", in Scientific journal of Khmelnytskyi National University, vol. 251, no.5, 2017. [Online]. Available: http://journals.khnu.km.ua/vestnik/pdf/ekon/pdfbase/2017/VKNUES-2017-N5.pdf\#page=63. [in Ukrainian].

[10] "Commercial Code Ukraine", Bulletin of Verkhovna Rada of Ukraine. [Online]. Available: https://zakon.rada.gov.ua/laws/show/436-15. [in Ukrainian].
[11] European Commission, "Definition of SMEs", 2019. [Online]. Available: https://ec.europa.eu/growth/smes/business-friendlyenvironment/sme-definition en.

[12] State Statistics Service of Ukraine, 2019. [Online]. Available: http://www.ukrstat.gov.ua/operativ/operativ2012/fin/osp/osp_u/osp_u .htm. [in Ukrainian]

[13] Report on the state of the SME sector in Poland: statistical report / Polish Agency for Enterpreneurship Development, Warsaw, 2018. [in Polish].

[14] Strategy for Small and Medium-sized Enterprise Development in Ukraine until 2020, approved by Instruction of the Cabinet of Ministers of Ukraine no. 504-p dated May 24, 2017 / Cabinet of Ministers of Ukraine, 2018. [in Ukrainian].

[15] Arbiana Govori, "Factors Affecting the Growth and Development of SMEs: Experiences from Kosovo", Mediterranean Journal of Social Sciences MCSER Publishing, vol. 4, no. 9, 2013. [Online]. Available: https://pdfs.semanticscholar.org/dfe6/b474b02ab5708c1d6e2751f84f7 d7de7676c.pdf.

[16] Chuthamas Chittithaworn, Dayang Hasliza Muhd Yusuf, Md. Aminul Islam, "Factors Affecting Business Success of Small and Medium Enterprises (SMEs) in Thailand", Asian Journal of Social Science, vol. 7, no. 5, 2011.

[17] Entrepreneurship development strategy: expert vision, 2016. [Online]. Available: http://platforma-msb.org/wpcontent/uploads/2016/10/strategy_prn_new.pdf.

[18] Enterprise Surveys. Ukraine, 2013. [Online]. Available: http://www.enterprisesurveys.org/data/exploreeconomies/2013/ukrain

[19] T. H. Vasyltsiv, T. O. Skrypko, "Economic risks and threats to investment and innovation activity of small and medium-sized enterprises", Economics. Management. Entrepreneurship, vol. 25 (II), no. 2, pp. 199-205, 2013. [Online]. Available: http://nbuv.gov.ua/UJRN/ecmepi_2013_25\%282\%29_25. [in Ukrainian].

[20] S. H. Dryha, "Current trends of small business development in EU countries", Efficient economy, no. 4, 2009. [in Ukrainian].

[21] D. V. Liapin, "Main models of development of small enterpreneurship in Ukraine", Strategic Prioritets, vol. 20, no. 3, pp. 90-95, 2011. [in Ukrainian].

[22] Y. H. Matviyishyn, "Entrepreneurship development support in Ukraine", Actual Problems Of Economics, vol. 184, no. 10, pp. 107112, 2016. [in Ukrainian]. 